\title{
High-Performance Work System and Employee Innovation Performance: The Role of Obse and Power Distance Orientation
}

\author{
Luying Chai, Yuchun Xiao* \\ School of Business Administration \\ Zhejiang Gongshang University \\ HangZhou,China \\ 1115277069@qq.com,xiaoyuchun2006@126.com
}

\begin{abstract}
Through the questionnaire survey of 296 company employees, this study explores the mechanism of highperformance work system how to influence employee innovation performance at the individual level. The results show that :(1) high performance work system is positively correlated with employee innovation performance;(2) organization-based selfesteem plays a partial mediating role in the relationship between high performance work system and employee innovation performance;(3) the power distance orientation of employees moderates the relationship between high performance work system and innovation performance, and also moderates the mediating effect of organization-based self-esteem on the relationship between high performance work system and innovation performance.
\end{abstract}

Keywords-High performance work system; Organizationbased self-esteem; Power distance orientation; Innovation performance

\section{INTRODUCTION}

With the continuous development of "Internet +" economy, innovation is a necessary condition for a company to gain sustainable competitive advantage. Company technology innovation ability will bring the unique products and services for the company, company management innovation makes employees have high commitment to an organization, which lead to sustainable competitive advantage for the companies [1]. Employees are the core of the company, and their innovation is the inexhaustible power and source of company innovation. Therefore, to improve the company's innovation performance, it is necessary to develop and improve the innovation ability of individual employees [2].

Previous studies on performance mainly focused on organizational performance and paid less attention to innovative performance. Studies on the impact of HRM practices on employees' innovative performance were even more less. Up to now, the research on the impact of high performance work system on the individual innovation performance and its internal impact mechanism is still a "black box" in the research field [3]. High performance work system is a practical activity developed by the organizational level, the information asymmetry between leaders and employees can easily lead to the difference in employee perception, thus influencing the implementation effect of the high-performance work system. Therefore, it is of great value to explore the influencing mechanism of employees' perception of high performance work system on innovation performance and the mediating effect of organization-based self-esteem.

Relevant studies have pointed out that internal factors and organizational cultural values of some organizations can affect the relationship between the high performance work system and employee attitudes implemented by companys [4][5][6][7].Power distance, as an organizational context variable, is an important part of organizational cultural values. Previous studies focused on the power distance tendency caused by cultural differences in different countries, but ignored the influence of the differences in power distance tendency of individuals in organizations under the same cultural background. Based on the individual level and the Internet industry as the research background, this study explores the influence of power distance tendency on the employee's perception of high performance work system and the relationship between innovation performance, and reveals its situational role in the organization.

\section{THEORY AND HYPOTHESES}

\section{A. High Performance Work System and Employee Innovation Performance}

High-performance work system can be regarded as a collection of human resource work practices, which have synergistic effects and promote each other, thus improving organizational efficiency and effectiveness [8][9][10]. Previous studies have shown that the practice system of human resource management in an organization can positively affect the innovative behavior and innovative performance of employees. Chen et al. explored the positive relationship between strategic human resource management system and innovation performance from the perspective of knowledge management, and verified the mediating role of knowledge management ability [11]. Ehrnrooth and Bjorkman used psychological authorization as the mediating variable to verify that HRM system can promote the innovation performance of employees [12]. Chiang et al. verifies the positive relationship between perception of high performance work system and employee innovation performance [13]. 
From the perspective of the implementation process of a high-performance work system, different employees will have different understandings and interpretations of the practices in the same high-performance work system, and thus generate different behaviors and attitudes [14]. Employees' perception of high performance work system implemented by the organization obviously affects the final implementation effect. Therefore, individual perception plays an important role in the effect of high performance work system implemented by the organization. To sum up, the study believes that employees' perception of high performance work system has a significant impact on their innovation performance, and employees' positive perception has a certain promoting effect on their innovation performance. Accordingly, this study proposes the following hypothesis:

Hypothesis 1: high performance work system perceived by employees is positively related to its innovation performance.

\section{B. The Mediating Role of Organization-Based Self-Esteem}

Self-determination theory pointed out that selfdetermination is a kind of potential about experiential choice. Individuals make free choices about their own actions based on a full understanding of their needs and environmental information [15]. Self-concept plays an important role in the process of motivation formation, and individual internal psychological and external environment factors promote idividual behaviors. The satisfaction of individual internal psychology will promote self-fulfillment, thus forming intrinsic motivation[16].

Practices in high-performance work system provide employees with the possibility to improve their abilities, motivations and opportunities, and convey the important and valuable signals to employees that employees are in the organization [17]. Chen et al. verified through empirical evidence that employee's perception of human resource practices implementation plays a complete mediating role between the human resource practices and perceived organization support [18]. According to self-determination theory, experiencing the care and support of the organization, employees can clearly perceive their own importance in the organization and form a stable self-concept, which stimulates individual behavior consistent with self-concept. Zhang examined the positive relationship between employee perception of high performance work systems and work performance, which further verified that employees' perception of high performance work system plays a positive role in attitude and behavior [19]. Accordingly, this study proposes the following hypothesis:

Hypothesis 2: organization-based self-esteem mediates the relationship between employees' perceived high performance work system and innovation performance.

\section{Moderating Influence of Power Distance Orientation}

The individual power distance orientation in the organizational context indicates the extent to which employees in the organization accept the unequal distribution of power [20].In the organization, employees high in power distance orientation think that the leader has more power than the subordinate employees, and show obedience to the leader's decision. On the other hand, employees low in power distance orientation think that all people in the organization are relatively equal and have the right to express their thoughts and suggestions [21]. Employees low in power distance view participation behavior with distrust and resist active behaviors [22]. Power distance will affect employees' perception of high performance work system. Employees high in power distance orientation are more likely to reject the independent management practice, and do not consider the participation, training and internal promotion in the high performance work system as benefits to themselves. According to the social exchange theory, when employees can feel the positive investment of the organization, they will show more positive attitudes and behaviors in return. Low power distance employees are more receptive to high performance work system signal, and thought that it's a kind of investment, so the staff has displayed the trend of more positive behavior and attitude, which are more likely to show the creative ideas and behaviors and produce higher levels of innovation performance. Accordingly, this study proposes the following hypothesis:

Hypothesis 3: the power distance orientation moderates the relationship between employees' perception of high performance work system and their innovation performance. When the power distance is low, the relationship is stronger.

\section{METHOD}

\section{A. Sample}

The study collected data from Internet companies located in Hangzhou and Shanghai of the People's Republic of China to test the proposed model. 100 full-time employees and their respective 23 immediate supervisors are invited to participate in the study. The employees asked their respective supervisor to evaluate their innovation performance in the questionnaire. And 100 paper questionnaires were recovered. Besides, the study recovered 243 online questionnaires which were filled in by employees. In order to make the data of the study more authentic, the questionnaire that meets the following conditions is regarded as invalid. (1)The number of missing answers is 3 or more; (2) There is a clear contradiction between the filling of the reverse item and the other options in the questionnaire; (3) Check the same option for the whole questionnaire. A total of 296 valid questionnaires were obtained after screening the above conditions. Of the 296 employees, 53.04 percent were male, and 59.45 percent employees were at private Internet companies which are over 300 employees.

\section{B. Measures}

1) High-Performance work system: High-Performance work system refers to a combination of unique but interconnected HR management practices, such as selective staffing, extensive training, internal mobility, employment security, clear job descriptions, results-oriented appraisals, incentive rewards, and participation [23]. The study adopted a scale of 27 items developed by Sun et al. in the Chinese context and use a 5-point likert scale and all items were measured on a 5-point Likert scale ranging from strongly 
disagree (1) to strongly agree (5)., Sample items for HighPerformance Work System include "There are formal training programs to teach new hires the skills they need to perform their job," "the company provides a formal training program for employees to increase their chances of promotion".

A confirmatory factor analysis (CFA) for high-performance work system indicated that the eight-factor model fit the data well $\quad(\chi 2=61.429, \quad \mathrm{df}=18, \quad \mathrm{CFI}=0.978, \quad \mathrm{IFI}=0.978$, RMSEA $=0.090$ ), which suggested that the items were reasonable measures of their respective HR practices. The study followed the subscale aggregation approach to average across all high-performance work system items for the score on high-performance work system. Cronbach's $\alpha$ for the subscales showed by the analysis, including selective staffing, extensive training, internal mobility, clear job descriptions, results-oriented appraisals, incentive rewards, and participation, was0.849, 0.748, 0.847, 0.854, 0.748, 0.747, 0.856, 0.842, which displayed good internal reliability. The Cronbach's $\alpha$ for high-performance work system was 0.855 .

2) Organization-based self-esteem: Organization-based self-esteem refers to that employees consider themselves competent and valuable as a member of the organization in the organizational context. The scale of 10 items developed by Pierce et al. has been widely used in domestic and foreign studies [24]. This study adopted the 5-point likert scoring method, namely $" 1=$ completely disagree, 5= completely agree". Sample items for Organization-based self-esteem include "The company (department) takes me seriously", "I am important in the company (department)". The study demonstrated good reliability and validity $(\alpha=0.880$, $\chi 2=59.112, \mathrm{df}=35, \mathrm{CFI}=0.977, \mathrm{IFI}=0.977, \mathrm{RMSEA}=0.048)$.

3) Innovation performance: Employee innovation performance refers to that the individual carries out the creation, promotion and implementation of the innovation thought intentionally which includes three stages of thinking generation, thought promotion and thought realization. A scale of 8 items developed by Han et al. was adopted [25]. The study used the 5-point Likert-type Scale, that is, "1= completely disagree, $5=$ completely agree". Sample items for innovation performance include "I provide new ideas for improving my current situation, and I find new working methods, skills or tools through learning". The scale, which combines the views of Janssen and Van Yperen, was compiled in the Chinese context and has $\operatorname{good} \operatorname{validity}(\chi 2=31.951$, $\mathrm{df}=18, \mathrm{CFI}=0.983, \mathrm{IFI}=0.983, \mathrm{RMSEA}=0.051$ ) [26]. The Cronbach's $\alpha$ for innovation performance was 0.864 .
4) Power distance orientation: The individual power distance orientation in the organizational context indicates the degree to which employees accept the unequal distribution of power. The power distance scale developed by Dorfman and Howell was adopted [27]. The scale contains 6 items and has good reliability and validity. In this study, 5-point Likert-type Scale was adopted, that is, $1=$ completely disagree, 5= completely agree". Sample items for power distance orientation include "most decisions of managers do not need to consult subordinates, and managers should less solicit opinions of employees". The scale has good validity $(\chi 2=19.105, \quad \mathrm{df}=8, \quad \mathrm{CFI}=0.980, \quad \mathrm{IFI}=0.981$, RMSEA=0.069). The Cronbach's $\alpha$ for power distance orientation was 0.829 .

5) Control variables: This study focuses on the Internet industry. This paper controls some variables that may affect employees' organization-based self-esteem and innovation performance, including gender, working years, education degree, position, company type and company scale.

\section{RESULTS}

Through the correlation analysis of high performance work system, organization-based self-esteem, innovation performance and power distance orientation, it can be seen from the Table I that high performance work system is significantly positively correlated with individual innovation performance and organization-based self-esteem. The organization-based self-esteem of employees is positively correlated with their innovation performance. Power distance tends to be negatively correlated with high performance working system, organization-based self-esteem and innovation performance.

\section{A. High Performance Work System and Employee Innovation Performance}

According to the Table II, all the fitting indexes of the constructed main effect model are within the acceptable range. The direct path coefficient of high performance work systems and innovation performance was 0.598 , and high performance work system has significant positive effect on innovation performance, namely the more perfectly high performance work system implemented, the more effectively high performance work system can promote the individual innovation performance, the higher innovation performance levels, which supports hypothesis 1 .

TABLE I. MEANS, STANDARD DEVIATION AND CORRELATION

\begin{tabular}{|l|l|l|l|l|l|}
\hline \multicolumn{1}{|c|}{ Variables } & \multicolumn{1}{c|}{ M } & \multicolumn{1}{c|}{ SD } & \multicolumn{1}{|c|}{$\mathbf{1}$} & $\mathbf{2}$ \\
\hline 1.HPWS & 3.5212 & 0.780 & 1 & \\
\hline 2.OBSE & 3.3378 & 0.670 & $0.547^{* *}$ & 1 & \\
\hline 3.Innovation performance & 3.2504 & 0.736 & $0.571^{* *}$ & $0.540^{* *}$ & 1 \\
\hline 4.Power distance orientation & 2.5749 & 0.743 & $-0.133^{*}$ & $-0.211^{* *}$ & $-0.215^{* *}$ \\
\hline
\end{tabular}


TABLE II. HIGH PERFORMANCE WORK SYSTEM AND INNOVATIVE PERFORMANCE ANALYSIS

\begin{tabular}{|l|l|l|l|}
\hline & \multicolumn{1}{|c|}{ Standardized path coefficients } & \multicolumn{1}{|c|}{ P } & \\
\hline Gender $\rightarrow$ Innovation performance & -0.123 & 0.016 & - \\
\hline Position $\rightarrow$ Innovation performance & 0.000 & 0.998 & - \\
\hline Education degree $\rightarrow$ Innovation performance & $0.222^{* * *}$ & $<0.001$ & - \\
\hline Working years $\rightarrow$ Innovation performance & -0.012 & 0.814 & - \\
\hline Company type $\rightarrow$ Innovation performance & -0.038 & 0.448 & - \\
\hline Company size $\rightarrow$ Innovation performance & -0.100 & 0.048 & - \\
\hline HPWS $\rightarrow$ Innovation performance & $0.598^{* * *}$ & $<0.001$ & support \\
\hline Fitting Index: $\chi 2 / d f=2.816$, RMSEA $=0.078, \mathrm{GFI}=0.852, \mathrm{CFI}=0.881, \mathrm{IFI}=0.882, \mathrm{TLI}=0.867$ & & \\
\hline
\end{tabular}

\section{B. The Mediating Role of Organization-Based Self-Esteem}

It can be seen from the Table III that the fitting indexes of the mediation model are all within the statistical standards, and the fitting effect is good. The direct effect of high performance work system on individual innovation performance was 0.242 , the indirect effect was 0.152 and the total effect was 0.394. Through bootstrap analysis of the model, the lower limit and upper limit of the indirect effect of high performance work system on innovation performance are 0.122 and 0.369 , thus it can be seen that the confidence interval does not include 0 . Therefore, the influence of high performance work system on individual innovation performance is significant through the mediating effect of organization-based self-esteem. Hypothesis 2 is supported.

\section{Moderating Influence of Power Distance Orientation}

Moderating effect test results was shown in the Table IV, to make innovation performance as the dependent variable regression, model 1 shows high performance work systems impact on innovation performance significantly $(\beta=0.537, p<$ 0.001);Model 2 shows that high performance work systems and power distance orientation into the equation of innovation performance at the same time, the power distance orientation impact on innovation performance significantly $(\beta=0.139, p<$
0.01); Model 3 tended to get high performance work systems, power distance, the interaction of high performance work systems and power distance orientation to join into equation, indicating that power distance orientation moderates the relationship between high performance work system and innovation performance significantly $(\beta=0.051, \mathrm{p}<$ 0.01 );Model 5 and 6 respectively show that high performance work systems $(\beta=0.548, \mathrm{p}<0.001)$ and power distance orientation $(\beta=0.165, \mathrm{p}<0.001)$ significantly impact on organization-based self-esteem; In Model 7, organization-based self-esteem was used as the dependent variable, high performance work systems and power distance interaction of regression coefficient is significant $(\beta=0.038, \mathrm{p}<0.01)$; In Model 4, the innovation performance was used as the dependent variable, high performance work system, organization-based self-esteem, power distance orientation, high performance work systems and power distance orientation interaction to join into equation, the regression coefficient of self-esteem significantly $(\beta=0.308, p<0.001)$, the interaction of organization-based self-esteem regression coefficients was not significant $(\beta=0.039, \mathrm{p}>0.1)$. Therefore, power distance orientation moderates the relationship between high performance work system and innovation performance, which is based on the mediating role of organization-based selfesteem, therefore, hypothesis 3 was verified.

TABLE III. BOOTSTRAP RESULTS: THE EFFECTS OF THE THREE FACETS OF HPWS ON EMPLOYEE INNOVATION PERFORMANCE VIA OBSE AND POWER DISTANCE ORIENTATION

\begin{tabular}{|l|l|l|}
\hline & \multicolumn{1}{|c|}{ Direct effect path coefficient } & P \\
\hline HPWS $\rightarrow$ OBSE & 0.423 & 0.001 \\
\hline OBSE $\rightarrow$ Innovation performance & 0.388 & 0.001 \\
\hline HPWS $\rightarrow$ Innovation performance & 0.242 & 0.001 \\
\hline & Indirect effect path coefficient & P \\
\hline HPWS $\rightarrow$ OBSE $\rightarrow$ Innovation performance & 0.152 & 0.001 \\
\hline & Total effect path coefficient & \\
\hline HPWS $\rightarrow$ Innovation performance & 0.394 & \\
\hline Fitting Index: $\chi 2 / d f=2.006$, RMSEA $=0.058$, CFI $=0.895$, IFI $=0.895, \mathrm{TLI}=0.887, \mathrm{NFI}=0.811$ & \\
\hline
\end{tabular}


TABLE IV. REGRESSION ANALYSIS OF PERSON-ORGANIZATION FIT'S MODERATING

\begin{tabular}{|c|c|c|c|c|c|c|c|}
\hline \multirow{2}{*}{ Variables } & \multicolumn{3}{|c|}{ Innovation performance } & & \multicolumn{3}{|c|}{ OBSE } \\
\hline & Model 1 & Model 2 & Model 3 & $\begin{array}{l}\text { Model } 4 \\
\end{array}$ & Model 5 & Model 6 & Model 7 \\
\hline Gender & $-0.111 * *$ & $-0.118^{*}$ & -0.120 & -0.110 & -0.022 & -0.030 & -0.031 \\
\hline Position & 0.005 & 0.016 & 0.057 & 0.001 & 0.020 & 0.033 & 0.029 \\
\hline Working years & -0.016 & -0.045 & -0.039 & -0.025 & -0.016 & -0.050 & -0.045 \\
\hline Education degree & $0.207 * *$ & $0.181 * *$ & $0.184^{* *}$ & $0.205^{* *}$ & -0.041 & -0.072 & -0.070 \\
\hline Company size & -0.091 & $-0.102 *$ & 0.047 & -0.079 & -0.044 & -0.058 & -0.053 \\
\hline Company type & -0.032 & -0.039 & 0.056 & -0.019 & -0.048 & -0.056 & -0.053 \\
\hline HPWS & $0.537 * * *$ & $0.524 * * *$ & $0.536 * * *$ & $0.369 * * *$ & $0.548 * * *$ & $0.533 * * *$ & $0.541 * * *$ \\
\hline Power distance orientation & & $-0.139 * *$ & $-0.142 * *$ & $-0.090^{* *}$ & & $-0.165 * * *$ & $-0.168 * * *$ \\
\hline HPWS*power distance orientation & & & $-0.051 * *$ & -0.039 & & & $-0.038^{* *}$ \\
\hline OBSE & & & & $0.308^{* * *}$ & & & \\
\hline $\mathrm{R} 2$ & $0.379 * * *$ & $0.396^{* * *}$ & $0.399 * * *$ & $0.462 * * *$ & $0.305^{* * *}$ & $0.330 * * *$ & $0.332 * * *$ \\
\hline$\Delta \mathrm{R} 2$ & 0.364 & $0.380^{* *}$ & $0.388 * * *$ & 0.443 & 0.288 & $0.312^{* *}$ & $0.311 * * *$ \\
\hline $\mathrm{F}$ & $25.075^{* * *}$ & $23.556^{* * *}$ & $21.075^{* * *}$ & $24.496 * * *$ & $18.059^{* * *}$ & $17.690^{* * *}$ & $15.764 * * *$ \\
\hline
\end{tabular}

\section{DISCUSSION}

It has been pointed out that the relationship between high performance work system and work performance is not simply linear. This study verifies the mediating role of organizationbased self-esteem between high performance work system and individual innovation performance through data analysis. Employees perceive that the more organization invest in employees, the more employees tend to show positive attitudes and behaviors. For the same human resource practices, individual perceptions of employees are different [14].When employees accepted the correct cognition of practice activities, they has the correct understanding of organization, and will have a positive psychological perception, for its own value in the organization can produce higher judgment, namely to promote the individual organization self-esteem level of ascension, as a result, employees with a positive attitude and behavior are more likely to engage in innovative activities, thus have a higher level of innovation performance.

This study data analysis results show that the employee's power distance tends to weaken the positive effect on high performance work system and innovation performance: When employees tend to be low in power distance, the relationship between high performance work systems and innovation performance is stronger, and when employees tend to be high in power distance, the relationship between high performance work systems and innovation performance is weaker. It's because that when employees tend to have a higher power distance, they are more likely to accept the unequal distribution of rights in the organization, keep an accepting attitude towards the decision and do not expect to participate in the decision, and they are more inclined to hide their views in the organization., so employees high in power distance tend to understand the rules and regulations of the organization.
Compared with employees in low power distance, employees high in power distance can realize the organization of high performance work systems for their own development more accurately, employees low in power distance lack of initiative and enthusiasm to organization activities, thus shows lower levels of innovation, namely the innovation performance level is lower.

\section{IMPLICATIONS}

Everyone has a different understanding of the system implemented by the organization, which will lead to the implementation of high-performance work system coming with different effects for different employees. In order to achieve good implementation effect, the human resource management personnel of the organization should carry out detailed communication about various human resource management activities to the leaders of all levels, and then convey to other employees, so as to avoid the misunderstanding caused by information asymmetry.

According to the research conclusion, it can be found that the organization-based self-esteem plays a mediating role between the perception of high performance work system and innovation performance, which indicates that the organization should pay more attention to the self-esteem level of employees in the organization. organization should develop various welfare policies in the organization so that employees can truly experience the organization's input and maintain a high level of organization-based self-esteem .

The moderating effect of employee power distance orientation indicates that the organization should pay attention creating low-power distance atmosphere. The cultural values in company will have a great influence on employees' behavior 
and attitude. Leaders and subordinates should have more informal communication. During the meeting, employees should be given more opportunities to participate and speak, so that employees can participate in the decision-making and improve their enthusiasm.

\section{LIMITATIONS AND FUTURE RESEARCH DIRECTIONS}

Due to the limitations of the research method, the data coverage of this study is limited, and different industries and natures of companys may have different impacts on the measurement and analysis results. Therefore, the application scope of this study conclusion is small. Subsequent studies can be more diversified and expanded in the selection and range of samples.

The paper and online questionnaire were used in the questionnaire collection method in this study, among which the paper questionnaire was collected by leader and employee pairing method, and the online questionnaires were filled by employees. Although Harman single factor test showed no serious common method deviation, its existence was inevitable. In subsequent studies, sample measurements of independent and dependent variables should be ensured to be separated.

The model designed in this study mainly focuses on the individual level, and takes the system perspective on high performance work system as the research variable without considering the specific impact mechanism of various practical activities. According to the research needs, follow-up studies can be conducted separately for each practice activity, the role and importance of high performance work system in the organization can be discussed in detail.

\section{REFERENCES}

[1] P.G. James, S.S. Chester, and O.N. Robert, "Correlates and consequences of high involvement work practices: the role of competitive strategy," International Journal of Human Resource Management, vol. ED-13, pp. 183-197, 2002.

[2] T.M. Amabile, R. Conti, H. Coon, J. Lazenby, and M. Herron, "Assessing the Work Environment for Creativity," Academy of Management Journal,vol. ED-39, pp. 1154-1184, 1996.

[3] J. Paauwe, "HRM and Performance: Achievements, Methodological Issues and Prospects," Journal of Management Studies, vol. ED-46, pp. 129-142, 2010.

[4] V.A. Ruth and C.D. John, "The role of human resource management in cross-border mergers and acquisitions," International Journal of Human Resource Management, vol. ED-15, pp. 1355-1370, 2004.

[5] S.C. Schneider, "Strategy Formulation: The Impact of National Culture," Organization Studies, vol. ED-10, pp. 149-168, 1989.

[6] L. Aitziber and L. Jon, "The moderating effect of cultural context in the relation between HPWS and performance: an exploratory study in Spanish multinational companies," International Journal of Human Resource Management, vol. ED-22, pp. 3949-3967, 2011.

[7] E. Appelbaum, T. Bailey, P. Berg, and A.L. Kalleberg, "Manufacturing Advantage: Why High-Performance Work Systems Pay Off," The Academy of Management Review, 2000, pp. 259.

[8] J. Horgan and M. Peter, "Human resource systems and employee performance in Ireland and the Netherlands: a test of the complementarity hypothesis," International Journal of Human Resource Management, vol. ED-17, pp. 414-439, 2006.
[9] J.P. Macduffie, "Human Resource Bundles and Manufacturing Performance: Organizational Logic and Flexible Production Systems in the World Auto Industry," Industrial \& Labor Relations Review, vol. ED-48, pp. 197-221, 1995.

[10] S.M. Toh, F.P. Morgeson, and M.A. Campion, "Human resource configurations: investigating fit with the organizational context," Journal of Applied Psychology, vol. ED-93, pp. 864-82, 2008.

[11] C. Chen and J. Huang, "Strategic human resource practices and innovation performance: the mediating role of knowledge management capacity," Journal of Business Research, vol. ED-62, pp. 104-114, 2009.

[12] M. Ehrnrooth and I. Björkman, "An integrative HRM process theorization: Beyond signalling effects and mutual gains," Journal of Management Studies, vol. ED-49, pp. 1109-1135, 2012.

[13] Y.H. Chiang, Y.H. Hsu, and H.A. Shih, "Erratum to: Experienced high performance work system, extroversion personality, and creativity performance," Asia Pacific Journal of Management, vol. ED-32, pp. $825-825,2015$.

[14] D.E. Bowen and C. Ostroff, "Understanding HRM-firm performance linkages: The role of the "strength" of the HRM system," Academy of Management Review,vol. ED-29, pp. 203-221, 2004.

[15] E.L. Deci and R.M. Ryan, Intrinsic Motivation and Self-Determination in Human Behavior. Springer US, 1985.

[16] R.M. Ryan and E.L Deci, "Self-determination theory and the facilitation of intrinsic motivation,social development,and well-being," American Psychologist, vol. ED-55, pp. 68-78,2000b.

[17] S. Aryee, F.O. Walumbwa, E.Y. Seidu, and L.E. Otaye, "Impact of High-performance Work Systems on Individual-and Branch-level Performance: Test of a Multi-level Model of Intermediate Linkages," Journal of Applied Psychology,vol. ED-97, pp. 287-300, 2012.

[18] J.A. Chen, S. Cheng, and M.Y. Chen, "Research on the internal formation mechanism from supportive human resource practice to organizational support," Journal of management, vol. ED-14, pp. 519$527,2017$.

[19] J.W. Zhang, L.R. long, and T.L. wang, "Impact of high performance work system on employee work performance: perspective of selfconcept," Management review, vol. ED-29, pp. 136-146, 2017.

[20] M. Clugston, J.P. Howell, and P.W. Dorfman, "Does cultural socialization predict multiple bases and foci of commitment?" Journal of Management, vol. ED-26(1), pp. 5-30, 2000.

[21] G. Hofstede, Culture's Consequences: International Differences in Work-Related Values. Beverly Hills: Sage. 1980

[22] Z.X. Chen and S. Aryee, "Delegation and employee work outcomes: An examination of the cultural context of mediating processes in China," Academy of Management Journal, vol. ED-50(1), pp. 226-238, 2007.

[23] L.Y. Sun, S. Aryee, and K.S. Law, "High-Performance Human Resource Practices, Citizenship Behavior, and Organizational Performance: A Relational Perspective," Academy of Management Journal, vol. ED-50, pp. 558-577, 2007.

[24] J.L. Pierce, D.G. Gardner, L.L. Cummings, and R.B, Dunham. Organization-based self-esteem: Construct definition, measurement, and validation. Academy of Management Journal, vol. ED-32(3), pp. 622648, 1989.

[25] Y. Ha, J.Q. liao, and L.R. long, "Modeling and empirical research on employee performance structure," Journal of management science, vol. ED-10, pp. 62-77, 2007.

[26] O. Janssen, and N.W. Van Yperen, "Employees' Goal Orientations, the Quality of Leader-Member Exchange, and the Outcomes of Job Performance and Job Satisfaction," Academy of Management Journal, vol. ED-47, pp. 368-384, 2004.

[27] P.W. Dorfman and J.P. Howell, "Dimensions of national culture and effective leadership patterns: Hofstede revisited," Advances in International Comparative Management, vol. ED-3, pp. 127-150, 1988. 